Teosofia: Indonesian Journal of Islamic Mysticism, Vol. 9, No. 2, 2020, pp. 207-226

e-ISSN: 2540-8186; p-ISSN: 2302-8017

DOI: $10.21580 /$ tos.v9i2.7332

\title{
BECOMING A MEANINGFUL HUMAN IN THE CONTEMPORARY ERA: Isyari's Interpretation of Human Fitrah in Risālah Al-Nür According to Said Nursi
}

\author{
Zaimul Asroor \\ Alumnus Sekolah Pascasarjana UIN Syarif Hidayatullah Jakarta \\ asroraim7@gmail.com \\ Cemal Sahin \\ Pascasarjana PTIQ Jakarta \\ hayratcemal@gmail.com
}

Article History: Received: 8 June 2020, Accepted: 28 October 2020, Published: 2 November 2020

\begin{abstract}
:
This paper wants to prove how Said Nursi's efforts to persuade humans to become meaningful (ma'nawi) humans through his interpretation of Risā lah al-Nūr. This tafsir, which is more Kalam and Isyāri (Sufi) in style, was Nursi's answer to his anxiety in facing the challenges of modernity in Turkey at that time (and is still relevant today). In the context of human nature, Nursi is aware that modernity has made humans fall into an attitude which he calls tafrid and ifrat in using his every senses (outer and inner senses). Therefore, with the characteristics and originality of his interpretation, he describes how people can return to their nature, namely by behaving 'adl or tawasut in all things. This is the man that he later calls as a meaningful human being. The methods that the author used in this research are descriptive-analysis methods and library research, by making tafsir Risā lah al-Nūr and tafsir Isyā rāt al-I'jā $z$ as primary sources, then supported by other secondary books which are still related to the theme.
\end{abstract}

Keywords: Human Nature, Human Meaningfulness, Outer-inner Senses, Tafsir Isyāri, Said Nursi

\section{A. Introduction}

$\bigcirc^{1}$ aid Nursi is one of the many modern commentators (mufassir) who lived in the late Ottoman era and the modern era (Kemal Ataturk). The struggle that he echoes is the struggle of monotheism. That is, the influence of the values of modernity, which often forgets the essence of human creation and who he is, makes Nursi's conscience move to invite them, especially the Turkish people, to return to the values of tawhìd. The values of monotheism are also one of the main discussions in Risālah al$N \bar{u} r$. Nursi believes, with strong faith, humans will not be fooled by all the material pleasures that modernity often promises even though they are only temporary. 
In explaining his thoughts and interpretations, Nursi often provides analogies and tamthì 1 of everyday life and even natural phenomena that humans experience so that they can easily understand them, including when he provides explanations about humans and how they can become meaningful (ma'nawi) humans. What the author says in this paper is one of the important themes in Risālah al-Nūr that is still relevant to human challenges in today's contemporary era.

\section{B. The Overview of Said Nursi}

Bedīuzzamān Said Nursi (1876-1960) has the real name Said bin Mirza. ${ }^{1}$ He lived in Three Eras at once; The Era of the end of the Ottoman Empire, the Colonial Era, and the Era of Independence. ${ }^{2}$ Nursi is also an important figure behind the emergence of the Nur movement (Said Nursi's students). ${ }^{3}$ The movement, numbering between six and nine million - mostly Turkish citizens - shares the same view on non-violent dialogue and tries to implement the teachings contained in the Qur'ān. ${ }^{4}$ The disciplines that Nursi mastered are very diverse. He mastered hadith, fiqh, kalām, tasawwuf, philosophy, science, and so on. ${ }^{5}$

One of the interesting things from the development of Nursi's thought, intellectuality and political attitude was when he finally divided his character into two: Old Said and New Said. Old Said (1876-1925) was a phase where Bedīuzzamān entered the political arena in the Ustmani Sultanate and tried to spread his ideas and influence. ${ }^{6}$ Meanwhile, New Said (1925-1950) was a phase where Nursi withdrew from the crowd and isolated himself. He also resigned from his political life in Istanbul. ${ }^{7}$ A situation that has also been experienced by Hujjatul Islām Abū al-Hāmid al-Ghazālī.

Hakan Coruh revealed that there are striking differences between Old Said and New Said that need to be emphasized here. ${ }^{8}$ Judging from the way or methodology of

1 Ian S. Markham, Suendam Birinci Pirim, and Said Nursî, An Introduction to Said Nursi: Life, Thought and Writings (Farnham, Surrey; Burlington, VT: Ashgate, 2011).

2 Ustadi Hamsah, "Membaca Pemikiran Bediuzzaman Said Nursi Tentang Signifikansi Agama Dan Identitas Bagi Kemajuan Sosial," TEOSOFI: Jurnal Tasawuf Dan Pemikiran Islam 8, no. 2 (December 10, 2018): 351-72, https://doi.org/10.15642/teosofi.2018.8.2.293-314.

3 This movement became known as Nurculuk. The name Nurculuk was born from the government at that time, which wanted to discredit the students who studied Risalah Nur. Look at Hasan Horkuc, "New Muslim Discourses on Pluralism in the Post-Modern Age," American Journal of Islam and Society 19, no. 2 (April 1, 2002): 68-86, https://doi.org/10.35632/ajis.v19i2.1971.

4 Ian S. Markham, "The Qur'an Revealed: A Critical Analysis of Said Nursi's Epistles of Light, ColinTurner, Gerlach Press, 2013," Reviews in Religion \& Theology 22, no. 3 (2015): 281-83, https://doi.org/10.1111/rirt.12529.

5 Hakan Coruh, Modern Interpretation of The Qur'an: The Contribution of Badi'uzzaman Said Nursi (Switzerland: Springer, 2019), 29.

6 Rahmah Bt. Ahmad H. Osman, "Imam Bediüzzaman Said Nursi's Concept of Tolerance as a Pillar of Moderation and Unity," The Journal of Risale-i Nur Studies 1, no. 1 (2018): 17-32.

7 Coruh, Modern Interpretation of The Qur'an: The Contribution of Badi'uzzaman Said Nursi, 23.

8 Coruh, 24. 
Nursi in serving Islam, New Said's life was filled with seclusion and was more focused on teaching theology based on the Qur'an and basic beliefs such as the oneness of God and the day of resurrection. Old Said was marked by Nursi's passion in revitalizing the Ottoman sultanate and the Islamic world as a whole. However, New Said was more interested in dedicating himself to explaining the meaning of the verses of the Qur'an.

There is another phase in Nursi's life which he calls Third Said (1950-1960). In the last ten years of his life, Risālah al-Nūr's work has increasingly spread among society and was opposed to the ideology of communism. Nursi also paid more attention to political developments. This is evidenced by how he provided guidance to the government through letters, students and his personal relationships with several representatives of the people from the Democratic Party. However, even though Nursi gave support and guidance to this party, he did not allow his students to be actively involved in politics. Nursi argued that this party was only a tool to "help" students and followers in the struggle against communism and atheism. Finally, after carrying out various kinds of struggles, Bediuzzaman took his last breath in Urfa, a province in eastern Anatolia, on March 23, 1960. ${ }^{9}$ He also made a testament to keep his grave secret for fear that people on pilgrimages had the wrong intention (not to seek the pleasure of Allah) and also in order to maintain the sincerity of the Risālah al-Nūr. ${ }^{10}$

\section{The Method of Interpretation of Risālah al-Nūr}

Before getting into the main discussion, the writer first wants to briefly present the method of interpretation in Risālah al-Nū $r^{11}$ so that it helps a little to get to know the description of this interpretation. As is generally known in the study of 'Ulüm alQur'ân, so far the scholars have divided the understanding or interpretation of the alQur'an into three; tafsìr bi al-Ma'tsūr (based on al-Qur'an and Sunnah), bi al-'Aqזi (based on reason) and bi al-Isyāri or Sufi (based on impressions). ${ }^{12}$ In this respect, it can be said that most of Nursi's interpretations fall into the third category (al-Isyā $n \bar{n})$. He himself confirmed that his interpretation is in the category of maknawi or isyari interpretation. ${ }^{13}$ So, if it follows the modern ulama's categorization that includes isyari as a style or Laun at-Tafsìr, then Risālah al-Nūr can also be said to use the isyari/ma'nawi/sufi and kalam styles (because he also discussed a lot in terms of faith

9 Coruh, 25.

10 Sukran Vahide, Biografi Intelektual Badiuzzaman Said Nursi: Transformasi Dinasti Ustmani Menjadi Republik Turki, ed. Nur Rofiah, trans. Sugeng Haryanto and Sukono (Jakarta: Anatolia, 2013), 48586.

11 During the last four decades of his life, Nursi focused on writing and distributing Risālah al-Nūr, Zeynep Akbulut Kuru and Ahmet T. Kuru, “Apolitical Interpretation of Islam: Said Nursi's FaithBased Activism in Comparison with Political Islamism and Sufism," Islam and Christian-Muslim Relations 19, no. 1 (January 21, 2008): 99-111, https://doi.org/10.1080/13510340701770311.

12 Quraish Shihab, Kaidah Tafsir, 3rd ed. (Tangerang: Lentera Hati, 2015), 349.

13 Said Nursi, Maktubat (Istanbul: Altinbasak, 2012), 250-53.

Teosofia: Indonesian Journal of Islamic Mysticism, Vol. 9, No. 2, 2020 
or kalam). One of the reviewers of Risalah Nur, Hakan Coruh, said that Nursi was a scholar who tried to "kalamisation" (kalamisasi) of interpretation, in contrast to Abduh who tried to "interpret" other disciplines. ${ }^{14}$ As for the interpretation method, this interpretation falls into the category of maudhu'i interpretation, which is interpreting verses based on certain themes. On the other hand, Nursi also very often uses analogy or mithāl to make it easier for the reader to understand his ma'nawi's interpretation. Then, it is not an exaggeration if the author also believes that Nursi's interpretation is also in addition to being isyari in style as well as aqli at once.

It is also important to note that before Nursi wrote Risā lah al-Nūr, he first wrote his tafsir, Isyā $\bar{r} \bar{t}$ al-I'jāz. This work is an interpretation which emphasizes the balaghoh aspect and the beauty of the language of the Qur'an. This work includes only the interpretation of two surahs, al-Fatihah and al-Baqarah. Forced not to be continued for various reasons. Among them were too long, took a lot of time and did not suit the needs of the Turkish people at that time. ${ }^{15}$

\section{Human in Nursi's Perspective}

The interpretation of Risā lah al-Nūr has three main elements in the object of its discussion: Allah, humans and the universe. ${ }^{16}$ In this case Said Nursi also discusses the problem of humans in detail according to the characteristics of his interpretation. According to him, humans are like the most valuable and big fruit in the "tree of the universe". Humans are also a reflection (tajalli) of the names of Allah, the most glorious verse or sign in the universe - besides being given the ability by Allah who is infinite. ${ }^{17}$

Humans are also seen by Nursi as travelers (musā fir) and guests of Allah who are glorious in the world. In order to do this noble duty he is given a lot of potential and a very wide capacity. Because of that, people who came or were born into this world should really ask themselves. For example, "Why did he come and be present in this world? Who brought him? Then — after he died — where would he go?" Regarding this question, Nursi gave an example of a comparison. He said, "If someone is asleep somewhere, but when he wakes up suddenly on the plane, he will automatically be confused and ask some questions that are almost the same as the questions above. This is where humans in this world should keep asking about the benefits of their existence." $18^{18}$

14 Coruh, Modern Interpretation of The Qur'an: The Contribution of Badi'uzzaman Said Nursi, 56. See also Resid Haylamaz, 'Islam's Universality and the Risale-i Nur's Method of Interpreting the Qur' an's Universality," TSAQAFAH 10, no. 2 (November $30, \quad 2014$ ): 245-78, https://doi.org/10.21111/tsaqafah.v10i2.188.

15 Said Nursi, Isyā rāt Al-I'jāz Fi Madzan Al-Ijaz, 3rd ed. (Kairo: Dar al-Kutub al-Misriyyah, 2002).

16 Nursi, Maktubat, 377-78.

17 Said Nursi, Sozler (Istanbul: Altinbasak, 2009), 102-3.

18 Said Nursi, Lemalar (Istanbul: Altinbasak, 2008), 17. 
Nursi also gave a different meaning between the terms basyar and insān. Basyar is defined by him as the way we see humans only from a physical and materialistic point of view. Meanwhile, Nursi understood insan as the way we view humans from the side of their meaning. The potential possessed by humans can also be a cause for understanding the purpose of their creation. However, he stressed, the potential that exists in man is likened to a seed, which can only develop and grow through knowledge and worship. ${ }^{19}$ With this knowledge and worship, he deserves to be labeled "Insan", namely as a meaningful (ma'nawi) human. ${ }^{20}$ On the other hand, indeed Allah created angels and gave them mind. However, He did not give them the power of lust (syahwat) and anger (amārah). Besides, they also only do what Allah commands them to do. Therefore, the angels' station (maqām) will always be stable. It is because they are not held responsible which causes their levels to go up or down. They are also not given a test by Allah, because the test occurs between two choices, and in this case the Angels cannot choose.

Moreover, with the existence of animals. Allah did not create him with mind, but He gave him an instinct, lust and anger. Therefore, animals are also not subject to responsibility because their lust and anger are not controlled and directed by reason. Moreover, the nature, emotions and feelings of animals are also limited by Allah. For example, a lion who hunts, eats and tore up poor sheep will never be criticized by his actions. This is because they cannot think of other alternatives. In fact, that is what they eat in order to survive. ${ }^{21}$

On the other hand, humans are indeed different from animals. Animals do not have knowledge of everything related to life. Therefore, he must learn all things. ${ }^{22}$ From this, humans are called very ignorant (jahū $I$ ) creatures and need many things, unlike animals, who only think about a few things while in the world. Animals only need one to two months (even within a day or two to learn what they need). This fact is like teaching humans how such animals have been created perfectly in another world (before the world). In contrast to humans, which can only stand after one to two years. He was only able to distinguish which one was dangerous and which one was beneficial after he was old enough. ${ }^{23}$

Back to human discussion. Allah gave them the power of lust, anger and reason. Consequently, within them there is an angelic nature (i.e. the power of reason) as well as an animal nature (i.e. lust and anger). Allah also does not limit all of these powers with anything, which is why humans are tested with their freedom of choice. ${ }^{24}$ On the

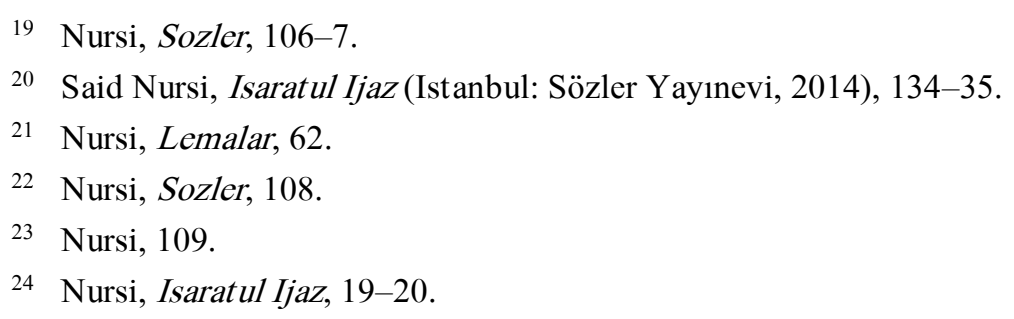


other hand, with His perfect qudrah, Allah created many things from one thing, as $\mathrm{He}$ led that one thing to carry out many tasks. He also wrote "a thousand and one books" on one page. Likewise Allah created a very complete species. That is, Allah created humans who are one kind of creature to carry out the many tasks with various levels that are usually carried out by animals. Allah does not place limits on human nat ure and feelings. ${ }^{25} \mathrm{He}$ also gave freedom to humans. This is different from the limited power and feelings of all animals, their nature is also limited. It's just that all human power leads to infinite sides, as if they continue to wander and strive into a wide and unlimited scope (for example, the various discoveries and developments of science are the result of the unlimited creativity and human desire to achieve what they want.author). ${ }^{26}$ From this, Nursi reminded that in essence humans are a mirror or manifestation of the names of Allah, the Owner of the infinite Universe. ${ }^{27}$

The explanation above can be a basic understanding and strong reasons why humans are given unlimited potential. For example, humans are "given" the world as a whole. Indeed, with their greedy nature they always feel less and continue to want more. With this greedy nature (which arises from animal lust), humans are also willing to make thousands of people suffer for their own sake (for example: colonialism.author). Thus, humans are exposed to various moral levels, from the despicable to finally leading to levels like Namrud and Pharaoh. According to Nursi, this kind of human model really bears the nature of tyranny. ${ }^{28}$ However, on the other hand, humans are also exposed to various degrees of glory, from the basic rank to the infinite high level. This highest level is what we know as the levels and degrees of the Prophets and Siddíqinn.

\section{E. Interpretation of Human Nature (Fitrah)}

When talking about human nature, Nursi bases his interpretation on the following three verses:

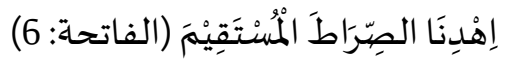

"Show us the straight path,"

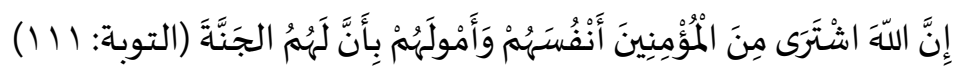

"Indeed, Allah buys from the believers, both themselves and their assets, by giving them heaven."

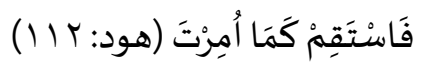

"Then remain thou (Muhammad) (on the right path), as has been ordered to you."

5 Nursi, Lemalar, 371-72.

Nursi, 364.

27 Nursi, Sozler, 103.

28 Nursi, Isaratul Ijaz, 135. 
In the three verses above, Nursi emphasizes his discussion on the theme of hospitality with human nat ure. This opinion can be said to be somewhat different from the salaf ulama 'who generally interpret istikamah as "following the Prophet's sunnah because he is a good example ${ }^{29}$ and also because during the course of his life, there is no excessive and extreme character in him." ${ }^{30}$ Unlike Nursi, especially in analyzing human nature, he sees istikamah from the side of how humans can be fair in maintaining their emotions and feelings. ${ }^{31}$ If traced, this opinion is not much different from the views of al-Ghazāli, ${ }^{32}$ Ibn Sina, ${ }^{33}$ al-Farābī ${ }^{34}$ and Plato. ${ }^{35}$

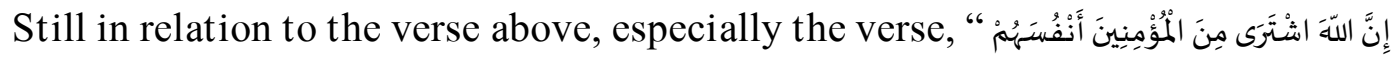

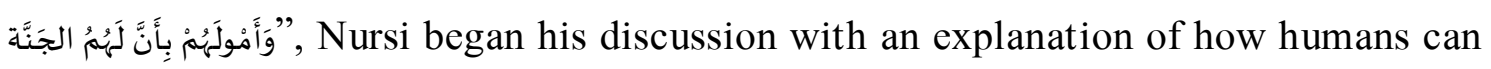
"sell" (the outer and inner senses) to Allah. When viewed, the above verse places the discussion of human lust before wealth. According to Nursi, the word "anfusahum" means human nature, which is related to how humans can "sell" their nature to God. According to him, Allah created and then sent humans into this world whose main purpose was for "infestation". In essence, all human beings also do not have property, but from the start they have what is later called fitrah (the outer and inner senses). This fitrah is the main asset of all human beings, so Allah wants to buy this fitrah from the believers.

If we look at the brief description above, it seems that Nursi's thought is very complicated about the meaning that "Allah wants to buy human nature". Therefore, to understand in detail, Nursi gives the following tamthìl:

One day, a king gave two large plots of land to two of his citizens. The field - in the eyes of the king — was nothing but a mandate. The king also equipped the field with various facilities such as factories, various types of machines, horses and weapons. But some time later the war was raging. The king also knew that it was very likely that the various facilities he had provided and provided earlier-if not saved — would have been plundered

29 Fahreddin Er-Rāzī, Mefătīḥu'l-Ġayb (Beirut: Dar al-Fikr, 1981), XVIII, 70-71; XXVII, 121-22; XXVIII, 12; Sühreverdî, Awārifu-l-Mààrif(Viçinde, n.d.), 53-54.

30 Nursi, Lemalar, 61-62.

31 Nursi, Isaratul Ijaz, 17.

32 Abū Hāmid Al-Gazzatī, Ihyả ‘ulūm Al-Dīn, vol. III (Leiden: Brill, 1963), 63-64; Abū Hāmid AlGazzali, Eyyühe'l-Veled (Bağdad, 1968), 42-43.

33 Ibn Sīnā, 'ilmü'l-Ahlāk (Kahire: Mecma u'r-resā’il içinde, 1908), 152-56; Ibn Sīnā, Eş-Şifầ'I: Elilāhiyyāt, ed. İbrāhim Medkūr (Kahire, 1924), 441-42, 453-56.

34 Farābī, El-Medînetü'l-Fāżıla (Kahire: Matbaatü'n-Nīl, 1968), 10, 20, 22, 54, 87-88; Farābī, Tahṣīlü'sSa āde (Haydarābād, 1926), 32, 44-45; Farābī, Et-Tenbīh 'alā Sebīli's-Sa'āde (Haydarābād, 1927), 914; Farābī, Es-Siyā setü'l-Medeniyye (Haydarābād, 1927), 29, 33; Farābī, Fuṣ ûlün Münteze'a, trans. Mâcid Fahrî, vol. II (Beyrut, 1978), 71-80.

35 Eflātun, Devlet, trans. Sabahattin Eyüboğlu and M. Ali Cimcoz (Istanbul, 1985), IV, 427b-434e; Aristotales, 'ilmü'l-Akhlāk, trans. A. Lütfi Es-Seyyid (Kahire, 1924), I: 2.6-9, 6.5; III: 7.1; V: 1, 1-3, 3.1-3, 4.7, 5.8-13, 6.6 .

Teosofia: Indonesian Journal of Islamic Mysticism, Vol. 9, No. 2, 2020 
and would even perish because of the effects of war. Then, because the king had high concern and affection, he sent a messenger to the two people to convey his message. The message reads, "Sell my trust to me. Let me take care of it so that your belongings and possessions are not lost in vain. Later when the war is over I will give back-all of that stuff-in a better condition. Because it is as if all of these assets belong to you, I will pay a high price to you. I will also use the machines and tools in the factory at my workplace. I will also increase the price and payment many times. Not only that, I will also give all the profits to you. I know you are weak and destitute, therefore you will not be able to pay for that great work. I also bear all costs associated with managing these assets. Apart from that, I will also leave the fine equipment in your hands until your task ends.

On the other hand, if you don't sell it to me, you will see that no one is able to keep whatever is in his hand, it will slip out of your grasp. It will disappear for nothing and you will never get a high price. And the most severe, you will receive punishment for betraying the mandate. If you sell to me, you will become my soldiers and act on my behalf, you will also become special soldiers and be free to be with the king. ${ }^{36}$ After they heard the king's advice and orders, one of the wise men of them said, "Carry out the orders! I will sell it with great pride and even I am very grateful. Another person who was defeated by pride, selfishness, and was already seduced by the life of the world said, "No! who is the king? I don't know him and I will not sell what is mine. I will not waste my treasure."

In short, the first person was finally promoted so that this made one other person jealous of him. The first one received a gift from the king. He also lived happily in a magnificent palace. Meanwhile, one other person ended up living in pain. Even everyone did not sympathize with him and said that he deserved this bad luck because his property was lost due to his mistakes and negligence. They also said that it was fitting for him to accept punishment and suffer hardships. ${ }^{37}$

From the long tamtsil explanation above, Nursi invites us to parse the essence of everything. He said, "O lust that is very much eager! Look at the real nature that can be seen through this ibrah. The real king is Allāh, Rabb al-Khāliq (who created creatures). He is the ruler of the entire universe, the Supreme and Immortal. All (description) fields, factories, machines and war equipment are the treasures that you have. It also includes what is in you, such as body, spirit, heart, five senses; eyes, hands, ears, tongue, mind and so on. The king's noble envoy in the tamtsil was Rasulullah SAW. Meanwhile, the command of the king who was very wise was al-Qur'an alKarim."38

\footnotetext{
36 Nursi, Sozler, 11.

37 Nursi, 12-13.

38 Nursi, 14.
} 
From the explanation above, it can be understood that Nursi was very skilled in providing various examples that made modern society at that time, including in the present era, easy to understand how the real nature we face in this world. He seemed to want to convey that sometimes, without realizing it, what is entrusted and mandated by Allah is considered our absolute possession. We are often reluctant to give back this mandate to Allah, whether through alms, zakat, etc. Nursi tried to give signs to this sense of belonging. In a sense, that everything that humans have is nothing but a mandate. If humans can sell this human "nature" - that is, the fitrah as someone who is essentially weak, has nothing, etc. — then he will become a lucky human. After the author describes the human nature along with the analogy or tamtsil in Risā lah al-Nūr, then the author will explain how the details of the outer and inner senses according to Nursi.

\section{Outer Senses}

\section{a. Eyes (As Sense of Vision)}

Nursi defined eyes as a very important sense for the human spirit. According to him, the eye is like a "window" for the spirit to see the universe. Therefore, if the eye is not "sold" to Allah, it means that it is being sold to indulge lust. If the eye is used only to witness the scenery and beauty that is transitory and to strengthen lust, then the value of the eye will be like a servant of lust and anger. However, if he is "sold" to Allah, he will become a manifestation of His name, namely al-Bașì $r$. And when he (eye) looks at the universe with that manifestation, all the beauty that is in this universe will be eternal and eternal for him in heaven. So, here Nursi prioritizes "selling eyes", namely using eyes in lawful cases which can be a means to get the pleas ure of Allah SWT. This is what it means to "sell to God". With this also humans will get eternal eyes in heaven. As for "selling eyes" to lust, it can be likened to, for example, when it is used to see an unclean sight, strengthen lust, etc. This will also cause a lot of sin in that person. ${ }^{39}$

Nursi added that the human eye is very different from the eyes of other creatures. Allah has given the human eye the potential, which is to see all beauty and all colors, which other creatures cannot (see the beauty). For example: a horse. Horses can see only two colors: black and white. From here Nursi tries to ask a question (which he has actually answered himself). He asked, "Why can humans see all beauty? This is because the eye, seeing all this beauty, will be able to become someone's cause or wasilah towards ma'rifatullah."40

\section{b. Tongue (As Sense of Taste)}

\footnotetext{
39 Nursi, 16.
}

40 Nursi, 107.

Teosofia: Indonesian Journal of Islamic Mysticism, Vol. 9, No. 2, 2020 
The human tongue according to Nursi is also very different from the tongue or the sense of taste of other creatures. Humans can distinguish and enjoy all kinds of pleasures from their tongue because Allah bestows on humans many favors. ${ }^{41}$ When humans eat or enjoy something, this automatically becomes a cause for gratitude. ${ }^{42}$ So, Nursi said, if this tongue is "sold" to Allah, it means that he enjoys all the food and the taste of pleasure that is felt only to be a means of giving thanks and becoming a manifestation of the name ar-Razzā $q{ }^{43}$ For this reason, the tongue in this context becomes the investigator (mufattish) who controls all pleasures that are beautiful, good and lawful. Apart from that, he is also an impetus for talking about things that are lawful, away from backbiting and lying. It is this tongue that will finally find eternal pleasure in heaven.

Conversely, if this tongue is used to serve lust, then he will be like a doorman (al-Bawwāb) in a building. When someone wants to enter the building, the doorman does not check it first, but he immediately lets that person in - regardless of whether he is a criminal or a thief. In fact, it could also be that when the person bribed the guard, he would immediately invite him in. Likewise with the "fate" of the tongue, it will eat everything regardless of whether the food is produced from a lawful way or not. ${ }^{44}$

\section{c. Ears (As Sense of Hearing)}

Human hearing is also different from other creatures. In terms of listening, enjoying and distinguishing all kinds of sounds, it is different from animal hearing. According to Nursi, human hearing is a manifestation of the name Allah as-Samì'. How can humans "sell" their ears to God? Nothing but when man is able to hear the universe, the birds singing, lectures and all the kind words that cause him to remember and be close to Allah. After he is able to hear some of the above, Nursi thinks that this person has sold his hearing to Allah. On the other hand, if the ears are used to listen to sounds that cause despair, lust and lust, then that sound is like this is haram. Nursi also added that there were also votes that had not been determined by the Sharia. In this case it is determined and seen by how it affects the heart, spirit and soul. Will it be more inclined towards Allah and the hereafter or even more inclined towards the lusts and pleasures of the world. ${ }^{45}$

\section{Inner Senses}

\section{a. Mind/Reason}

41 Nursi, Lemalar, 147.

42 Nursi, Maktubat, 247.

43 Nursi, Lemalar, 5.

44 Nursi, Sozler, 18.

45 Nursi, Isaratul Ijaz, 106. 
Nursi explained that the power of reason is a tool that makes humans and angels have similarities. In a sense, humans and angels use reason to understand Allah and contemplate His creation. Nursi defines reason as "a tool that can distinguish between good and bad, harm and benefit." 46 Therefore, reason is a tool to distinguish all things. In this case, it can be seen that his view is different from that of Plato and Farabi, who said that reason is the main function of a person to achieve happiness in the world. ${ }^{47}$ On the other hand, it may also be said that in this regard Nursi's view was closer to that of Imam al-Ghazāli. ${ }^{48}$

So reason for Bedīuzzamān is not something perfect. But it becomes a means of knowing what is perfect and good. ${ }^{49}$ If this intellect is not used istiqamah (wasat), it will cause a lot of suffering. If reason were a kind of tool, then if it was not "sold" to Allah and not used to serve Him, then it would become a disgraceful, annoying and weak instrument. ${ }^{50}$ It becomes a tool that gives harm to and burdens the human mind -which is inherently very weak- with the suffering of the sad past and fear in the face of an uncertain future. ${ }^{51}$ Because of this, in Nursi's view, wicked people usually run away (looking for an outlet) by drunkenness and seeking vain entertainment. If the intellect were "sold" to the owner of reason, namely Allah, and then used in His name, it would certainly become a key capable of unlocking all the endless treasures of grace and wisdom in the universe. ${ }^{52}$ More than that, it (reason) will also rise to a commendable degree that is blessed by Allah who will prepare humans (as the owner of reason) to lead to eternal happiness.

So, in this case Nursi emphasized that if reason is used to indulge lust, it will bring about suffering. Because the pleasures of this world (nafsānī) are temporary. When the mind thinks about and warns that this pleasure will be finished, in that time its happiness will also be finished and turn into suffering. Therefore, lovers of the world (hubbu al-dunyā) who feel that the restlessness caused by their mind keeps bothering them, generally try to get rid of them by drunkenness. ${ }^{53}$ In this context, Nursi tried to relate it to the phenomenon of civilization in Europe at that time which greatly exalted reason but without being accompanied by revelatory values. That is why this

46 Nursi, 20.

47 Farābī, Me'āni'l-'aḳl, trans. Friedrich Dieterici (Leiden: E.J. Brill, 1895), 46; Farābī, El-Medínetü'lFāżıla, trans. A. Nader (Beyrut, 1986), 101-4.

48 Al-Gazzalī, Ihyả 'ulūm Al-Dīn, III:I: 88-95; III: 4; Abū Hāmid Al-Gazzalí, Mí yārü'l-'ilm, ed. Hasan

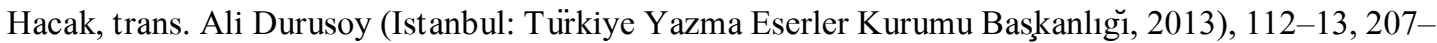
10; Abū Ḥāmid Al-Gazzalí, El-Münkıı Mine’ḍ-Ḍalâl, ed. Ǧamīl Șalībā and Kāmil Ayyād (Beyrut: Dār al-'Andalus, 1973), 6-7.

49 Nursi, Sozler, 99-101.

50 Nursi, 17.

51 Nursi, Lemalar, 8.

52 Nursi, Sozler, 18.

53 Nursi, 19.

Teosofia: Indonesian Journal of Islamic Mysticism, Vol. 9, No. 2, 2020 
exaltation of reason usually gave birth to tyranny in Europe. For example, the outbreak or occurrence of the first and second world wars. These two wars that once ravaged human civilization were the result of European "rational reason" at that time which was far from the spirituality of revelation. In my opinion, wars and colonialism in modern forms that are still happening are also the result of the use of reason without being accompanied by revelation values.

On the other hand, Nursi's opinion about reason can also be said to be somewhat closer to the mu'tazilah view which says that if reason is contrary to revelation, then reason is made the principle or basis and naql should be interpreted (ta' $\left.{ }^{\prime} \bar{l} /\right)^{54}$ However, Nursi noted that reason must be "educated" first by Islamic teachings and then it can be used as a basis or principle in interpreting ( $\left.\mathbf{t a}^{\prime} \mathbf{m} \bar{l}\right)$ naql. He also added that not everyone can interprete texts or naql which is contrary to reason. Only people who are pious and can take all the lessons from the Al-Qur'an have the authority to compose the Qur'an.

The author also sees that in almost every article of his writings Nursi emphasizes that reason occupies a very important position, but if there is a naql that is against logic, then he still accepts the argument of naql and tries to integrate it. Nursi did not reject the existence of hadist dho iff. From this point of view it differs from the opinion of Ibn Taymiyah, ${ }^{55}$ Abduh $^{56}$ and Rahman. ${ }^{57}$ On the contrary, he agreed with alGhazāli. ${ }^{58}$ Al-Ghazāli also in his work Ihȳ̄ ' wrote the hadiths, most of which, have no reference. ${ }^{59}$ Here Nursi has his own argument. He sees that if there is a hadith that contains or invites matters relating to morals and spiritual matters, even though it is very doif, then he does not reject it, because according to him the hadith can be practiced. A small example is when Nursi means the hadith " الدنيا علي ثور والحوت". Most modernist scholars reject this hadith and consider it as maudū , ${ }^{60}$ but in Nursi's view, the above hadith should not be rejected, on the contrary, it is sufficient to comment on it and seek lessons for it. According to him, the word "thaur" which means cow, and "al-hū $t$ " which means fish can be interpreted as very important information that human

54 Hüsnī Zeyne, El-' Aḳl inde'l-Mu'tezile (Beyrut, 1978), 18-21, 146.

55 Takıyyüddin Ahmed b. Abdülhalīm b. Teymiyye, Mecmû́ u Fetā vā, ed. Abdurrahman b. Muhammed, vol. I-XXXVII (Riyadh, 1991), 86.

56 James Robson, "Tradition, the Second Foundation of Islam," The Muslim World 41, no. 1 (January 1951): 22-33, https://doi.org/10.1111/j.1478-1913.1951.tb02505.x.

57 Fazlur Rahman, Islamic Methodology in History (Karachi: Central Institute of Islamic Research, 1965), 10-11; Fazlur Rahman, "Concepts Sunnah, Ijtihād and Ijmā' in the Early Period," Islamic Studies 1, no. 1 (1962): 5-21.

58 Ayşe Esra Ağırakça Şahyar, “Zayıf Hadisle Fezâil Konusunda Amel Edilebilirlik’ Fikrinin Doğuşu ve Gelişimi," Hadis Tetkikleri Dergisi 1, no. 1 (2003): 31-49.

59 Abdurrahman Bedevī, Mü' ellefâtü'l-Ġazzā Ii (Küveyt, 1977), 98-125.

60 Muhammed b. Abdillah Ebu Abdillah el-Hâkim en-Neysâbûrî, El-Müstedrek Ale's-Sahîhayn (Beyrut: Dâru'l-kütübi'l-ilmiyye, 1990), 4, 636; Muhammed Zekiyuddin El-Münziri, Et-Terğib ve't-Terhib (Beyrut: ei-Mektebetu'l-Asnyye, 1996), 4, 257. 
life can continue in this world because of two elements: sea and land. Life on land can continue with agriculture, which is based on the function of cows. Likewise with fish in the ocean that can be used by humans.

So, Nursi's method of interpreting naql which contradicts reason is quite close to Muhammad Abduh's method of interpretation. Because Muhammad Abduh when interpreting verses such as surah al-fil he commented that the $A b \bar{a} b \bar{l} l$ bird mentioned in the letter is a virus and disease. ${ }^{61}$ It can be seen that this modernist scholar tried hard to get closer to the argument of naql and aql. Nursi also discussed how reason can perfectly fulfill its duties. Nursi's famous saying, "The light of reason is science and knowledge, while the light of the heart is the science of religion. With a combination of the two, the essence will be revealed. If separated, science will cause skepticism and religious knowledge will cause fanaticism and ta'assub." 62 Therefore, Nursi was of the opinion that the two must be united. Here we can clearly see that reason functions to think, and for that it needs light. According to Nursi, this light comes from the science of kalam, science and philosophy. The light of the heart comes from religious knowledge such as hadith, akhlaq (moral), Sufism, jurisprudence, etc.

As it is known, Nursi from the beginning of his life was very ambitious to build Madrasah Az-Zahrā, ${ }^{63}$ which is a school or university that combines science and religion. Because of that he submitted a proposal to establish this university to Abdul Hamid II. Abdul Hamid II actually supported him by providing funds for the construction of the madrasa. However, due to the occurrence of World War I (as well as several other problems), this proposal was canceled. Whereas one of the reasons Nursi wanted to build this university was so that there would be no more rebellion by extremists in Eastern Turkey (none other than because there was no school that could combine the two elements above). ${ }^{64}$

In addition, Nursi, in his Isyā rat al-I'jā $z$ divides the levels of reason into three parts: First, the levels of deficiency and underestimation (tafint) which are defects. Second, the level of exaggeration, which is an act of excess (ifrät). Third, the middle level, namely justice ( 'adl). Thus, lacking in "power of intellect" ( Tafint al-Quwwah al'Aqliyyah) constitutes ignorance and stupidity. As for the excessive use of reason (ifrāt), it is a deceptive portrayal and a deep thoroughness. Meanwhile, the middle way of "intellectual power" is wisdom (hikmah) or tawassut. ${ }^{65}$ Related to this, Nursi made Surah al-Baqarah: 269 as the basis for his views:

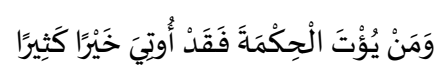

${ }^{61}$ Muhammed Abduh, Tefsīru Cüz' i 'Amme (Mesir: Mațbaatu'ş-Şa'b, n.d.), 157-58.

62 Said Nursi, Munazarat (Istanbul: Fayyaz Yayinlari, 2006), 63.

63 Abdulkadir Menek, Bediüzzaman Said Nursi İstanbul Hayati (Istanbul: Yeni Asya Neşriyat, 2008), 2, 40-45.

${ }^{64}$ Said Nursi, Tarihçe-i Hayat (Istanbul: Feyyaz Yayinlari, 2006), 227.

65 Nursi, Isaratul Ijaz, 17.

Teosofia: Indonesian Journal of Islamic Mysticism, Vol. 9, No. 2, 2020 
"And whoever is gifted with wisdom, he really has been awarded many gifts."

So, from the division of Nursi's mind above, it can be concluded that justice in the mind is a level of wisdom. ${ }^{66}$ If humans have maintained this level, then their intellect will become a place which manifests (tajalli) the name of Allah al-Hä kim. ${ }^{67}$ If this level (middle) is not fulfilled, then usually human morals tend to be despicable. Because it can also be said that people who have morals are people who have wisdom.

\section{b. Syahwat (Lust or Desire) and $A m \bar{a} r a h$ (Anger)}

Lust can be defined as a human desire to benefit, especially in terms of enjoyment. As for anger, it is a power that functions to ward off dangerous and destructive things. ${ }^{68}$ Said Nursi always uses these two terms simultaneously. According to him, these two emotions are very important in human life. Both also work instinctively. So-lust - wherever he sees pleasure, he always wants to reach and get it. That is, to move, human lust needs these two devices (lust and anger). It is from lust that then comes desire and love. Meanwhile, out of anger comes fear, worry and anxiety. According to Nursi, human lust and anger are not limited by Allah. So both of them are very strong and there are no limits. This is different from the lust and anger that exists in an animal which is limited by its natural disposition. Then, why doesn't Allah limit these two instincts in humans? Nursi explained, from him Allah asked man to limit himself, both of which were nothing but a test and at the same time a cause of human perfection. ${ }^{69}$ Thus, human perfection depends on the limitation of these two instincts. $^{70}$

As for the example of human lust when compared to that of animals, it will be seen that humans can have lust for everything in the universe. As for animals, their lust is very limited in the sense that animal desires are not as broad as human desires and lusts. Anger too, humans are very afraid of anything, sometimes even they are very afraid of viruses that cannot be seen. However, animals are not like that, they are only afraid of certain things. Therefore, according to Nursi, what can limit and control these two emotions is the power of reason. ${ }^{71}$ So, the power of reason is like a commander in the human body and nature. If so, how can humans control these two emotions? Nursi's

66 Al-Gazzalī, Ihyả 'ulūm Al-Dīn, I: 1-38; Abū Ḥāmid Al-Gazzalī, El-Ḥikme Fî Mahlūḳāti'llâh, ed. Muhammed Reşid Kabbani (Beyrut: Dari Ihyai'l-Ulum, 1986).

67 Nursi, Lemalar, 368.

68 Nursi, Isaratul Ijaz, 17, 18, 19.

69 Nursi, Sozler, 49-50.

70 Nursi, Isaratul Ijaz, 17, 18, 19.

71 Tehdzībü'l-ahlāk, ibn Miskeveyh, ed. Hasan Temîm (Beyrut, 1977), 37, 38, 40, 47; ỉhvân-1 Safâ, ErResầ il, ed. Butrus El-Bustânî (Beyrut, 1957), III: 312-315; ỉbn Sīnā, En-Necât, ed. Muhammed Takī Dânişpejûh (Tehran, 1985). 
explanation in this case is almost the same as Imam Ghazāli's view in Kimyah asSa'âdah. ${ }^{72}$

In Nursi's view, human lust has three levels. The first two levels are levels that lead to astray, corruption and humiliation ( $\operatorname{radz} l a h) .{ }^{73}$ The first two levels also fall into the category of ifrāt (excessive) and tafint (very lacking) levels. As previously explained, Ifrath can be interpreted as someone's desire to get everything which in turn can cause him to serve his lust. This trait can also make humans become like animals and put them in a state of fujür (lust against forbiddenness). So, Nursi said, human freedom depends on how he is able to control this excessive case. ${ }^{74}$ If he is able to limit excessive attitudes then he will become a free man. Freedom also does not mean being able to do whatever (hurriyah) humans want to do, but independence is if it is able to limit excessive attitudes itself. So, Nursi said that Allah wants humans to be free and safe from the authority of their lust.

As for tafrit, it can be interpreted as the absence of desire (lust) for anything, even for matters that are lawful (humūd). According to Nursi, this could also lead to damage, for example unmarried priests which in Islam are considered bad because it is like killing their lust. Humans who do not have lust cannot be considered perfect, because lust means "enjoying". If he is able to enjoy, there will be gratitude, the more grateful he is, his position will increase. ${ }^{75}$

Nursi argues that Sufism which keeps people away from the pleasures of the world in this 20th century (in Nursi's time) is also no longer compatible and does not benefit humans. ${ }^{76}$ This view is similar to that of Fazlur Rahman in his book Islam and Modernity. ${ }^{77}$ Similar views emerged from his predecessor, Abduh. Abduh also thought that the backwardness of Muslims was due to the existence of Sufism teachings that kept people away from the life of the world and only focused on spiritual matters. ${ }^{78}$ According to him, this factor makes Muslims lazy. According to Nursi, even the companions of the Prophet did not leave the world. Even though they get the highest position in the history of Muslims with this lust. So, from this Nursi ultimately believed that if Allah gave feelings and emotions, then both should be used and utilized, not turnedf off. The last level is the perfect stage which is called 'iffah. 'Iffah can be defined as having lust and desire for things that are lawful and not wanting to

72 Al-Gazzatí, Ihyả 'ulūm Al-Dīn, III:7, 9, 11, 48-107; Abū Ḥāmid Al-Gazzalí, Mîzânü'l-'amel, ed. Süleyman Dünya (Kahire: Dârü'l-Meârif, 1964), 19, 30-31. 36-37, 47, 54, 67-69.

73 Farābī, Tahșịlü’s-Sa'āde, ed. Ca‘fer Âlüyâsîn (Beyrut, 1983), 68-69, 71, 74.

74 Nursi, Munazarat, 88-89.

75 Nursi, Maktubat, 282.

76 Nursi, 445.

77 Fazlur Rahman, "The Post Formative Development in Islam," Islamic Studies 4, no. 1 (1962); Fazlur Rahman, Islam and Modernity (Chicago: University of Chicago Press, 1982), 14, 144.

78 Muhammed Abduh, El-A'mālü'l-Kāmile, n.d., II:23-26; III:511-527; IV:226; Reşīd Rızā, Tarikh AlUstadz Imam Shekh Muhammad Abduh, vol. I (Cairo: Dar al-Manar, 1931), 26, 106-30. 
do things that are forbidden. Nursi said that this level becomes an intermediate value (fair) between the two extreme poles above and becomes a perfect character. ${ }^{79}$

After giving an explanation of the distribution of lust, Nursi then explained about the anger which he divided into three levels. First, the level of tafint which means jabānah (fear of anything and don't want to take risks). According to Nursi, someone's excessive fear of taking risks will lead to poverty. Humans should not need to be afraid of something up to a limit of about $40 \%$. That is, if the percentage he is afraid of is up to $40-50 \%$, he should take the risk. This is none other than so that they get success in the world. ${ }^{80}$ Second, the level of ifrät which means tahawwur (not being afraid of anything). For example, if there is a very large risk (approx. 80\%) and the person is still taking risks, then this is not good. The two characteristics above (jabānah and tahawwur) can cause humiliation (radhilah). The third, middle level (justice and istiqamah), namely courage. He is a noble character (al-Jasārah). Courage can be interpreted as sacrificing oneself for happiness in this world and the hereafter. For example, jihad. If we sacrifice ourselves and die shahid, we will definitely get eternal happiness. As for world affairs, he takes more rational risks (risks that are below 40\%).

In Kimyah as-Sa'ādah, Imam al-Ghozali discusses these three powers, namely lust, anger and reason. ${ }^{81}$ However, Nursi then added a fourth strength, namely the nature of justice as an independent character. In this case, according to the author, Nursi tries to perfect al-Ghazāli's theory or idea by saying that justice is not actually a separate character or strength. On the contrary, it arises from the nat ure of wisdom, courage and 'iffah (as has been explained above). According to Nursi, a person is called fair if he is able to be fair to the three powers above (lust, anger and reason). If he is only able to be fair in one or two aspects, then his justice is still not perfect. However, if he is able to apply the three powers above, then he is entitled to be called a person who is truly just and has perfect morals. So, Nursi said that the sharia brought by the Prophet served to limit three powers: lust, anger and reason as well as to beautify them. ${ }^{82}$ Fazlur Rahman in his book The Major Themes of the Qur'an also said that the goal of Islam is to realize justice and good morals. ${ }^{83}$ In this case Said Nursi and Fazlur Rahman have the same thoughts. However, Nursi here thinks more philosophically and prioritizes human nature.

Nursi argues that human must be fair to their desires, in the sense that they still have to fulfill their desires provided that they do not go outside the limits of the Sharia. So, the verse "zolimun linafsihi" can be interpreted as a condition where someone does

79 Nursi, Isaratul Ijaz, 17-18.

80 Nursi, Maktubat, 423.

81 Abū Ḥāmid Al-Gazzâī, Kimyayi Saadet (Istanbul: Celik Yayinevi, 1996), 24, 279.

82 Nursi, Isaratul Ijaz, 98-99.

83 Fazlur Rahman, Islam (Chicago: University of Chicago Press, 1982), 32; Fazlur Rahman, "Divine Revelation and the Prophet," Hamdard Islamicus 2, no. 1 (1978): 66-72. 
not fulfill the needs of human desires according to Sharia. This desire will eventually complain to human. If the man has fulfilled the needs of his desire, it will not seek pleasure in an unlawful sphere. So, in essence, human can direct and control their desires. Therefore, following desire is man's own fault. Nursi added that if all human needs related to their desires are met then this will become worship. Hence, Nursi said that in this century we cannot follow one of the Sufism teachings, namely zuhū $d$ which means being far from enjoyment. This opinion is the same as what Muhammad Abduh had said in his book Risā lah at-Tauhị ${ }^{84}$

\section{F. Conclusion}

What can be concluded from the above information is that the interpretation of human nature that was initiated by Nursi actually has one core, inviting humans to use their desires in the right way to become meaningful or spiritual human beings in all eras and in all places and times. Meaningful (ma'nawi) humans are those who can put their potential fitrah (outer and inner) into a position that is 'adl and tawwassut. Not the other way around, falling at two different extreme poles: ifrāt (excessive) and tafint (very lacking). At the same time, this could be an answer to the challenges of the contemporary world which are clearly more challenging than the "world" that Nursi was facing at that time (modern).

84 Muhammed Abduh, Risāletü’t-Tevḥìd, ed. M. Reşīd Rizā (Kahire, 1947), 7-8, 19-20, 22-23, 47-58, 61-65, 89-114, 199-200. 


\section{Bibliography}

Abduh, Muhammed. El-A'mālü'l-Kāmile, n.d.

—. Risāletü't-Tevḥīd. Edited by M. Reşīd Rizā. Kahire, 1947.

—. Tefsìru Cüz'i 'Amme. Mesir: Maṭbaatu'ş-Şa’b, n.d.

Al-Gazzâ̄í, Abū Hāmid. El-Hikme Fî Mahlūkāti'llâh. Edited by Muhammed Reşid Kabbani. Beyrut: Dari İhyai'l-Ulum, 1986.

. El-Münkız Mine’ḍ-Ḍalâl. Edited by Ğamīl Ṣalībā and Kāmil Ayyād. Beyrut: Dār al-'Andalus, 1973.

—_. Eyyühe'l-Veled. Bağdad, 1968.

—. Ihyả 'ulūm Al-Dīn. Vol. III. Leiden: Brill, 1963.

—. Kimyayi Saadet. Istanbul: Celik Yayinevi, 1996.

—. Mîzânü'l-'amel. Edited by Süleyman Dünya. Kahire: Dârü'l-Meârif, 1964.

—. Mi yā rü'l-'ilm. Edited by Hasan Hacak. Translated by Ali Durusoy. Istanbul: Türkiye Yazma Eserler Kurumu Bașkanlığ, 2013.

Aristotales. 'İlmü'l-Akhlāk. Translated by A. Lütfi Es-Seyyid. Kahire, 1924.

Bedevī, Abdurrahman. Mü' ellefâtü'l-Ǵazzā ${ }^{1}$. Küveyt, 1977.

Coruh, Hakan. Modern Interpretation of The Qur'an: The Contribution of Badi'uzzaman Said Nursi. Switzerland: Springer, 2019.

Eflātun. Devlet. Translated by Sabahattin Eyüboğlu and M. Ali Cimcoz. Istanbul, 1985. el-Hâkim en-Neysâbûrî, Muhammed b. Abdillah Ebu Abdillah. El-Müstedrek Ale'sSahîhayn. Beyrut: Dâru'l-kütübi'l-ilmiyye, 1990.

El-Münziri, Muhammed Zekiyuddin. Et-Terğib ve't-Terhib. Beyrut: ei-Mektebetu'lAsnyye, 1996.

Er-Rāzī, Fahreddin. Mefā tịḥu'l-Ǵayb. Beirut: Dar al-Fikr, 1981.

Farābī. El-Medinetü'l-Fāżılla. Translated by A. Nader. Beyrut, 1986.

—. El-Međinnetü'l-Fāż̇la. Kahire: Matbaatü'n-Nīl, 1968.

—. Es-Siyā setü'l-Medeniyye. Haydarābād, 1927.

—. Et-Tenbīh 'alā Sebīli's-Sa'āde. Haydarābād, 1927.

—. Fuṣ̂ûün Münteze'a. Translated by Mâcid Fahrî. Vol. II. Beyrut, 1978.

_. Me'āni’l-'akl. Translated by Friedrich Dieterici. Leiden: E.J. Brill, 1895.

—. Taḥșīlü’s-Sa'āde. Edited by Ca'fer Âlüyâsîn. Beyrut, 1983.

—. Tahṣīlü’s-Sa'āde. Haydarābād, 1926.

Hamsah, Ustadi. "Membaca Pemikiran Bediuzzaman Said Nursi Tentang Signifikansi Agama Dan Identitas Bagi Kemajuan Sosial." TEOSOFI: Jurnal Tasawuf Dan 
Pemikiran Islam 8, no. 2 (December 10, 2018): 351-72. https://doi.org/10.15642/teosofi.2018.8.2.293-314.

Haylamaz, Resid. “Islam's Universality and the Risale-i Nur's Method of Interpreting the Qur'an's Universality." TSAQAFAH 10, no. 2 (November 30, 2014): 245-78. https://doi.org/10.21111/tsaqafah.v10i2.188.

Horkuc, Hasan. "New Muslim Discourses on Pluralism in the Post-Modern Age." American Journal of Islam and Society 19, no. 2 (April 1, 2002): 68-86. https://doi.org/10.35632/ajis.v19i2.1971.

Kuru, Zeynep Akbulut, and Ahmet T. Kuru. "Apolitical Interpretation of Islam: Said Nursi's Faith-Based Activism in Comparison with Political Islamism and Sufism." Islam and Christian-Muslim Relations 19, no. 1 (January 21, 2008): 99-111. https://doi.org/10.1080/13510340701770311.

Markham, Ian S. “The Qur' an Revealed: A Critical Analysis of Said Nursi's Epistles of Light, ColinTurner, Gerlach Press, 2013." Reviews in Religion \& Theology22, no. 3 (2015): 281-83. https://doi.org/10.1111/rirt.12529.

Markham, Ian S., Suendam Birinci Pirim, and Said Nursî. An Introduction to Said Nursi: Life, Thought and Writings. Farnham, Surrey; Burlington, VT: Ashgate, 2011.

Menek, Abdulkadir. Bediüzzaman Said Nursi Ístanbul Hayati. Istanbul: Yeni Asya Neşriyat, 2008.

Nursi, Said. Isaratul Ijaz. Istanbul: Sözler Yayınevi, 2014.

—. Isyārāt Al-I'jāz Fi Madzan Al-Ijaz. 3rd ed. Kairo: Dar al-Kutub al-Misriyyah, 2002.

- Lemalar. Istanbul: Altinbasak, 2008.

- Maktubat. Istanbul: Altinbasak, 2012.

-. Munazarat. Istanbul: Fayyaz Yayinlari, 2006.

- Sozler. Istanbul: Altinbasak, 2009.

—. Tarihçe-i Hayat. Istanbul: Feyyaz Yayinlari, 2006.

Osman, Rahmah Bt. Ahmad H. “Imam Bediüzzaman Said Nursi’s Concept of Tolerance as a Pillar of Moderation and Unity." The Journal of Risale-i Nur Studies 1, no. 1 (2018): 17-32.

Rahman, Fazlur. "Concepts Sunnah, Ijtihād and Ijmā' in the Early Period." Islamic Studies 1, no. 1 (1962): 5-21.

_. "Divine Revelation and the Prophet." Hamdard Islamicus 2, no. 1 (1978): 6672.

- Islam. Chicago: University of Chicago Press, 1982.

- Islam and Modernity. Chicago: University of Chicago Press, 1982.

_. Islamic Methodology in History. Karachi: Central Institute of Islamic Research, 1965. 
_. "The Post Formative Development in Islam." Islamic Studies 4, no. 1 (1962).

Rızā, Reşīd. Tarikh Al-Ustadz Imam Shekh Muhammad Abduh. Vol. I. Cairo: Dar alManar, 1931.

Robson, James. "Tradition, the Second Foundation of Islam." The Muslim World41, no. 1 (January 1951): 22-33. https://doi.org/10.1111/j.1478-1913.1951.tb02505.x.

Safâ, İhvân-1. Er-Resầ il. Edited by Butrus El-Bustânî. Beyrut, 1957.

Şahyar, Ayşe Esra Ağırakça. "Zayıf Hadisle Fezâil Konusunda Amel Edilebilirlik' Fikrinin Doğuşu ve Gelişimi.” Hadis Tetkikleri Dergisi 1, no. 1 (2003): 31-49.

Shihab, Quraish. Kaidah Tafsir. 3rd ed. Tangerang: Lentera Hati, 2015.

Sīnā, Ibn. 'İlmü'l-Ahlāk. Kahire: Mecma 'u'r-resā'il içinde, 1908.

—. EȘ-Şifầ I: El-İlāhiyyāt. Edited by İbrāhim Medkūr. Kahire, 1924.

Sīnā, İbn. En-Necât. Edited by Muhammed Takī Dânişpejûh. Tehran, 1985.

Sühreverdî. Awärifu-1-Ma'ärif. Viçinde, n.d.

Tehdzībü'l-ahlāḳ. Íbn Miskeveyh. Edited by Hasan Temîm. Beyrut, 1977.

Teymiyye, Takıyyüddin Ahmed b. Abdülhalīm b. Mecmû'u Fetāvā. Edited by Abdurrahman b. Muhammed. Vol. I-XXXVII. Riyadh, 1991.

Vahide, Sukran. Biografi Intelektual Badiuzzaman Said Nursi: Transformasi Dinasti Ustmani Menjadi Republik Turki. Edited by Nur Rofiah. Translated by Sugeng Haryanto and Sukono. Jakarta: Anatolia, 2013.

Zeyne, Hüsnī. El- 'Akl 'inde'l-Mu'tezile. Beyrut, 1978. 